\title{
Expression Profiles of 290 ESTs Mapped to Chromosome 3 in Human Epithelial Ovarian Cancer Cell Lines Using DNA Expression Oligonucleotide Microarrays
}

\author{
Emily N. Manderson, ${ }^{1}$ Anne-Marie Mes-Masson, ${ }^{2,3}$ Jaroslav Novak, ${ }^{5}$ Peter D. Lee, ${ }^{1,5}$ \\ Diane Provencher, ${ }^{2,4}$ Thomas J. Hudson ${ }^{1,5,6,7}$ and Patricia N. Tonin ${ }^{1,6,7,8}$ \\ ${ }^{1}$ Department of Human Genetics, McGill University, Montreal, Quebec H3A 1B1, Canada; ${ }^{2}$ Centre de recherche du Centre \\ Hospitalier de I'Université de Montréal (CHUM)-Hôpital Notre-Dame and Institut du cancer de Montréal, Montreal, Quebec \\ H2L 4M1, Canada; ${ }^{3}$ Département de médecine, et ${ }^{4}$ Département d'obstétrique-gynécologie, Université de Montréal, \\ Montreal, Quebec H3C 3J7, Canada; ${ }^{5}$ Montreal Genome Centre, McGill University Health Centre, Montreal, Quebec H3G \\ 1A4, Canada; ${ }^{6}$ Department of Medicine, McGill University, Montreal, Quebec H3G 1A4, Canada; ${ }^{7}$ Research Institute, McGill \\ University Health Centre, Montreal General Hospital, Montreal, Quebec H3G 1A4, Canada.
}

\begin{abstract}
We have investigated previously the utility of oligonucleotide expression microarray technology in an analysis of four spontaneously transformed epithelial ovarian cancer (EOC) cell lines, TOV-21G, TOV-81D, OV-90, and TOV-112D. Here, we examine the expression of 290 expressed sequence tags (ESTs) that map to human chromosome 3 in a primary culture derived from normal ovarian surface epithelium (NOSE), NOV-31, and the four spontaneously transformed EOC cell lines. One of these cell lines, OV-90, harbors a deletion of an entire chromosome 3p arm. Whereas the most aggressive cell lines (OV-90, TOV-112D, and TOV-21G) exhibited the highest levels of expression, assessed by the mean of expression values of all ESTs, OV-90 showed the lowest mean of expression of ESTs that map to the $3 p$ arm in comparison with TOV-112D and TOV-21G. This difference in expression profile of 3p ESTs in OV-90 is also reflected in the ratio of expression of ESTs on 3p versus the $3 q \mathrm{arm}$ and in that the expression values of ESTs that map to $3 p$ were more often lower than higher in OV-90 in two-way comparisons with NOV-31, TOV-21G, and TOV-112D. The loss of a 3p arm does not affect the pattern of differential expression in analyses based on the range of numeric expression values of each EST or fold differences in expression for each EST in comparison with NOV-31. However, 25 differentially expressed ESTs were identified on the basis of threefold differences in expression values between NOV-31 and any EOC cell line; and six of these ESTs were differentially expressed uniquely in OV-90. The investigation of these ESTs could facilitate the identification of novel chromosome 3 genes implicated in ovarian tumorigenesis.
\end{abstract}

Epithelial ovarian cancer (EOC) is the second most common malignancy of the female genital tract and is the fifth most common cancer in women (National Cancer Institute of Canada 2000). The prognosis of this disease is usually poor, as reflected in the high proportion of incident cases that result in death, as well as the fact that the $5 \mathrm{yr}$ survival rate is just under $30 \%$. This is predominantly due to the fact that EOC is often diagnosed at a late stage because of the lack of early warning symptoms. As a result, the molecular events underlying ovarian tumorigenesis remain largely unknown.

Cytogenetic studies have revealed that chromosome 3 is frequently rearranged in EOC, and these rearrangements often involve deletions of the short arm of chromosome 3 (Mertens et al. 1997). Loss of chromosome 3p in EOC has also been detected through loss of heterozygosity (LOH) studies and has been reported to occur at a frequency ranging from $13 \%-52 \%$, at various loci tested (Ehlen and Dubeau 1990;

${ }^{8}$ Corresponding author.

E-MAIL tonin@med.mcgill.ca; FAX (514) 934-8273.

Article and publication are at http://www.genome.org/cgi/doi/10.1101/ gr.174202.
Yang-Feng et al. 1992; Dodson et al. 1993; Cheng et al. 1996; Lounis et al. 1998; Fullwood et al. 1999). Functional evidence in support of a 3p gene important in EOC comes from a study by Rimessi et al. (1994) showing that microcell-mediated chromosome transfer (MMCT) of chromosome 3 into an ovarian cancer cell line induced senescence and growth arrest as well as suppression of tumorigenicity. Frequent overrepresentation of $3 q 26$ in ovarian cancer has been detected by comparative genomic hybridization (CGH) in several studies (Arnold et al. 1996; Sonoda et al. 1997; Sugita et al. 2000). CGH also showed that PIK3CA (3q26) is frequently increased in copy number, which may lead to increased transcription in ovarian cancer (Shayesteh et al. 1999). The combined results of cytogenetic, LOH, MMCT, and CGH analyses suggest that there is one or more genes located on chromosome 3 that are implicated in ovarian tumorigenesis.

We have utilized an in vitro model system to study the molecular genetic events important in EOC. This model system is based on the establishment of four spontaneously transformed EOC cell lines (TOV-21G, TOV-81D, OV-90, and TOV-112D) that display the phenotypes of the original tu- 
mors from which they were derived (Provencher et al. 2000). Recently, we analyzed this EOC model system using the Hs6000 DNA expression microarrays from Affymetrix (Tonin et al. 2001). Our results indicated that this new technology is a valid approach to study ovarian cancer in that the patterns of gene expression detected by the microarray are consistent with the phenotypes of the EOC cell lines.

The objective of this study is to examine the expression of ESTs on chromosome 3 in human EOC cell lines using DNA expression microarrays. Here we describe the expression patterns of 290 ESTs that map to chromosome 3 in a primary culture derived from normal ovarian surface epithelium

\section{A Mean Expression of ESTs Which Map to Chromosome 3}

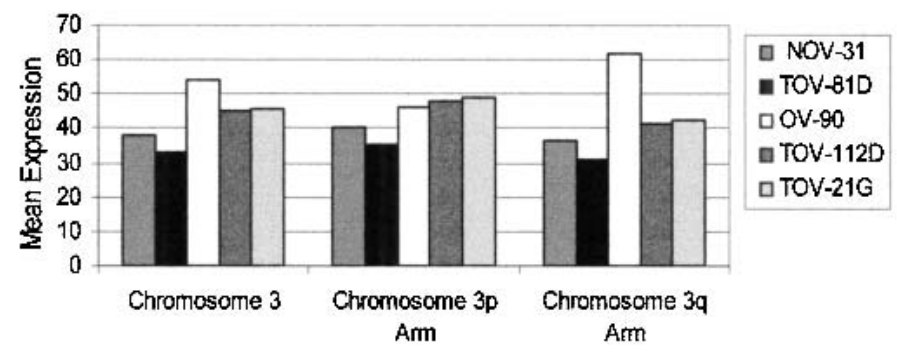

B Ratio of the Mean of Expression Values of Chromosome 3 and Each Arm: EOC cell lines vs. NOV-31

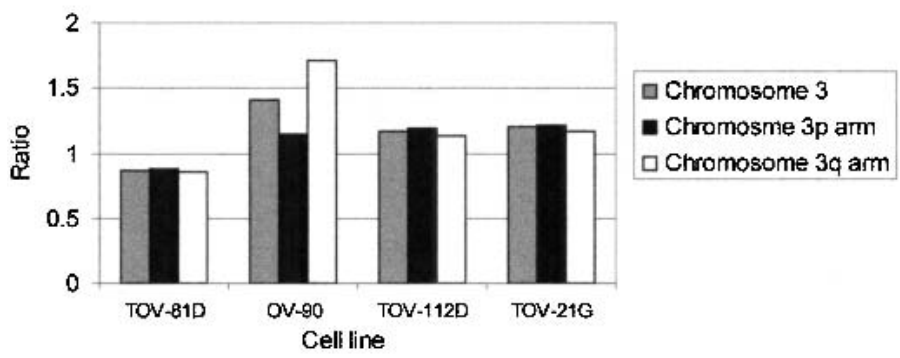

\section{Ratio of The Mean of Expression Values of ESTs: $3 p$ arm vs. $3 q$ arm}

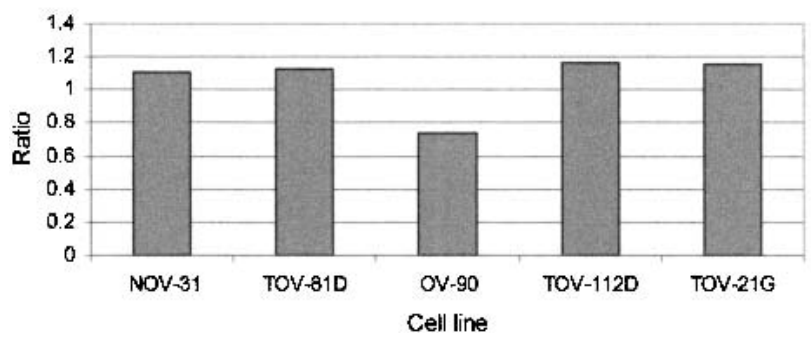

Figure 1 Analysis of the mean of the expression values of chromosome 3 mapped ESTs. The mean was calculated by adding the expression values of all ESTs and dividing by the total number of ESTs for each sample. ( $A$ ) The mean of the expression values of ESTs that mapped to the entire chromosome 3 and each arm separately was calculated for NOV-31 and the four EOC cell lines. (B) A comparison was made between NOV-31 and the EOC cell lines by dividing the mean of the expression values for each cell line by the mean of the expression values for NOV-31. (C) The results of comparisons of the mean of the expression values of ESTs that map to the $3 p$ arm to the mean of the expression values of ESTs that map to the $3 q$ arm. The ratio was calculated by dividing the mean of the expression values of ESTs that mapped to the $3 p$ arm by that of the $3 q$ arm for each sample.
(NOSE), NOV-31, and the four spontaneously transformed EOC cell lines. The OV-90 cell line has been shown by both karyotype and $\mathrm{LOH}$ analyses to harbor the complete loss of one chromosome 3p arm (Lounis et al. 1998; Provencher et al. 2000). Two methods of analysis were applied to analyze the expression data collected using the Hs6000 microarray. The first method is based on examining the overall expression of ESTs that map to chromosome 3, whereas the second method is based on examining the expression of individual ESTs in the cell lines in comparison with NOV-31.

\section{RESULTS}

A list of 290 ESTs that map uniquely to chromosome 3 was created by verifying the map information listed on the UniGene-Homo sapiens database in May 2000. There is an almost equal number of ESTs that map to the chromosome 3p arm and the chromosome 3q arm, 140 and 150 respectively. We analyzed the expression data of 290 ESTs that map to chromosome 3 in two different ways. First, we examined the overall expression of ESTs in the four EOC cell lines and NOV-31; secondly we identified ESTs that are differentially expressed between the EOC cell lines and NOV-31.

\section{Examination of the Overall Expression of ESTs That Map to Chromosome 3}

We calculated the mean of the expression values of ESTs (mean expression) that map to the entire chromosome 3 homolog and to each arm for each sample (Fig. 1A). The results show an increase in overall expression of ESTs that map to chromosome 3 in the three aggressive cell lines, OV-90, TOV-112D, and TOV-21G in comparison with the primary culture of NOSE, NOV-31. The least aggressive cell line, TOV-81D, shows levels of expression similar to that of NOV-31. The mean of the expression values of ESTs on the 3p arm for cell line OV-90 is greater than that for NOV-31, however, it is lower than the mean for the two other aggressive cell lines. There also appears to be an increase in the expression of ESTs that map to the $3 \mathrm{q}$ arm in OV-90 in comparison with NOV-31 and the other cell lines.

In an alternate analysis, we compared the mean of the expression values of ESTs for each cell line with that of NOV-31 (Fig. 1B). The results show that TOV-81D, TOV-112D, and TOV-21G have the same level of decrease or increase in expression in comparison with NOV-31, whether one examines the mean of expression of ESTs on the entire homolog or each arm separately. However, for OV-90, the ratio for ESTs that map to the 3p arm is lower than the ratio for the $3 q$ arm. In Figure $1 \mathrm{C}$, we compared the mean expression of ESTs on the $3 p$ arm with that of the mean expression of ESTs on the $3 q$ arm in each sample. This analysis was performed to establish whether there is a difference in the overall expression of ESTs between the two arms in the four EOC samples and NOV31 . This analysis has the advantage of comparing the expression of ESTs within a given sample (one microarray and one scan), instead of comparing across samples (multiple microarrays and multiple scans). The results show that the ratio approaches 1.0 for all samples with the exception of OV-90, for which the ratio is 0.74 . Figure $1 \mathrm{C}$ also indicates that the ratio of the mean expression of $3 p$ ESTs to the mean expression of $3 q$ ESTs is the same in NOV31 and the EOC cell lines, with the exception of OV-90. 
Two-way comparisons were performed between OV-90 and each of the other samples to examine the effect of the loss of one $3 p$ arm on the expression of individual ESTs in cell line OV-90. We counted the number of ESTs on each arm for which the expression value in OV-90 was either higher or lower than that of the other sample (Fig. 2). The results for the ESTs that map to the $3 p$ arm (Fig. 2A) show that there are more ESTs for which the expression value in OV-90 is lower than the value in NOV-31, TOV-112D, or TOV-21G. In the majority of cases in which the expression value is lower in OV-90, the magnitude of the difference is $<50$. The expression values of ESTs on the 3p arm are more often higher in OV-90 than in TOV-81D, and this is consistent with the finding that TOV-81D has the lowest mean of expression values of ESTs that map to chromosome 3 (Fig. 1A). The results for ESTs that map to chromosome 3q (Fig. 2B) show that there are more instances in which the expression value of an EST is higher in OV-90 in the two-way comparisons with all other samples; and this result is consistent with the observation that OV-90 has the highest mean of expression values of ESTs that map to chromosome 3q (Fig. 1A).

\section{Comparison of the Expression of Individual ESTs Between the EOC Cell Lines and NOV-31}

The methods of analysis used to examine the expression profile of individual ESTs that map to chromosome 3 are based on differences in the range of expression values for each EST or on ESTs displaying at least a threefold difference in expres-

\section{A Two-way Comparisons of the Expression Values of ESTs Mapped to Chromosome 3p}

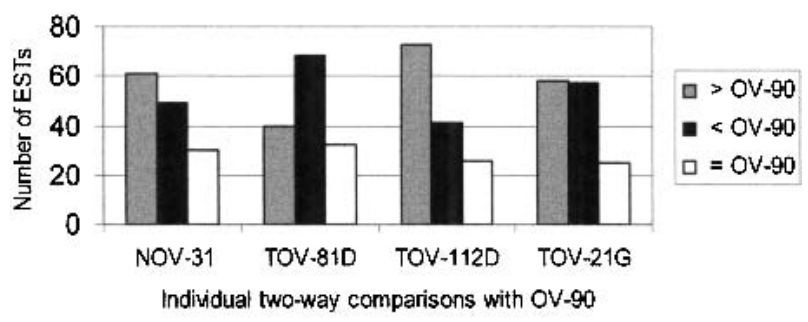

\section{B Two-way Comparisons of the Expression Values of ESTs mapped to Chromosome 3q}

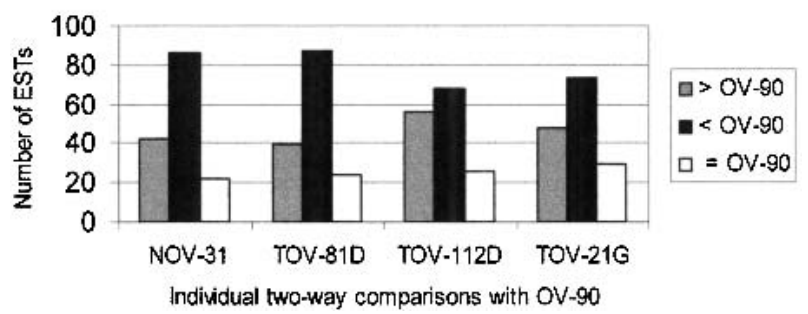

Figure 2 Two-way comparisons of the numeric expression value of individual ESTs between OV-90 and the other samples. The number of ESTs for which the expression value in OV-90 was lower than, higher than, or equal to the value in the sample with which it was being compared was counted. Expression values that were negative or zero were standardized to a minimum value of one for the purpose of making comparisons. The analysis was performed for ESTs that mapped to the $3 p$ arm $(A)$ and for ESTs that mapped to the $3 q$ $\operatorname{arm}(B)$. sion in any EOC cell line in comparison with NOV-31. A representative sample of comparisons using either method is shown in Figure 3, and the analysis of the entire data set is available at http://genome.mcgill.ca/ovarian.

Figure 3, panel A displays the ESTs that are differentially expressed based on their numerically assigned expression values categorized on the range of expression divided into five intervals: 1-49, 50-199, 200-499, 500-1000, and >1000 (Fig. $3)$. A total of 114 ESTs are differentially expressed based on the range of numeric expression value. The number of ESTs that are differentially expressed between NOV-31 and each cell line is listed in Table 1 . In the two-way comparisons, a similar number of ESTs were differentially expressed between NOV31 and each aggressive cell line, whereas the fewest number of differences were observed between NOV-31 and TOV-81D (Table 1).

The second method involves calculating the number of ESTs that are differentially expressed on the basis of at least a threefold difference in expression between any EOC cell line and NOV-31 (Fig. 3, panel B). As the expression values that fall below 50 have a high degree of variability (T.J. Hudson, pers. comm.), we calculated the fold difference after standardizing all data to a minimum value of 50. A total of 25 ESTs (Table 2) are differentially expressed with at least a threefold difference, which represents $9 \%$ of the total ESTs that were examined (two ESTs represent the transferrin receptor gene). The number of ESTs that are differentially expressed between NOV-31 and each cell line is listed in Table 1 . There are a similar number of ESTs that are differentially expressed in the two-way comparisons between NOV-31 and each aggressive cell line, and the fewest number of ESTs with a threefold difference in expression were detected in the comparison between TOV-81D and NOV-31. Only six ESTs are differentially expressed uniquely in the comparison between NOV-31 and OV-90 (Fig. 3, panel B).

\section{DISCUSSION}

In this study, we analyzed both the overall expression and the individual expression profiles of 290 ESTs that map to chromosome 3 in four EOC cell lines and NOV-31. When we examined the overall expression of ESTs that map to the entire chromosome 3 and each arm separately, we observed a trend to over-expression of ESTs in the three aggressive cell lines. However, OV-90 shows the lowest mean of expression of ESTs that map to the $3 p$ arm in comparison with TOV-21G and TOV-112D. This difference in expression profile of 3p ESTs in OV-90 is also revealed by the ratio of expression of ESTs on the $3 p$ arm versus the $3 q$ arm and the finding that the expression values of ESTs that map to 3p are more often lower than higher in OV-90 in two-way comparisons with NOV-31, TOV$21 \mathrm{G}$, and TOV-112D. The loss of a 3p arm in OV-90 does not affect the pattern of expression in analyses on the basis of the range of numeric expression values of each EST or fold differences in expression for each EST in comparison with NOV-31. Similar results were observed in an analysis of the impact of trisomy 17 on expression profiles of EOC cell lines using oligonucleotide microarrays (P.N. Tonin, unpubl.).

The fewest number of differences were observed between the expression profiles of NOV-31 and the least aggressive cell line, TOV-81D, in all methods of analysis. This is consistent with our previous findings that TOV-81D displayed growth characteristics similar to that of NOSE in that it is unable to form colonies in soft agarose or to form tumors in nude 


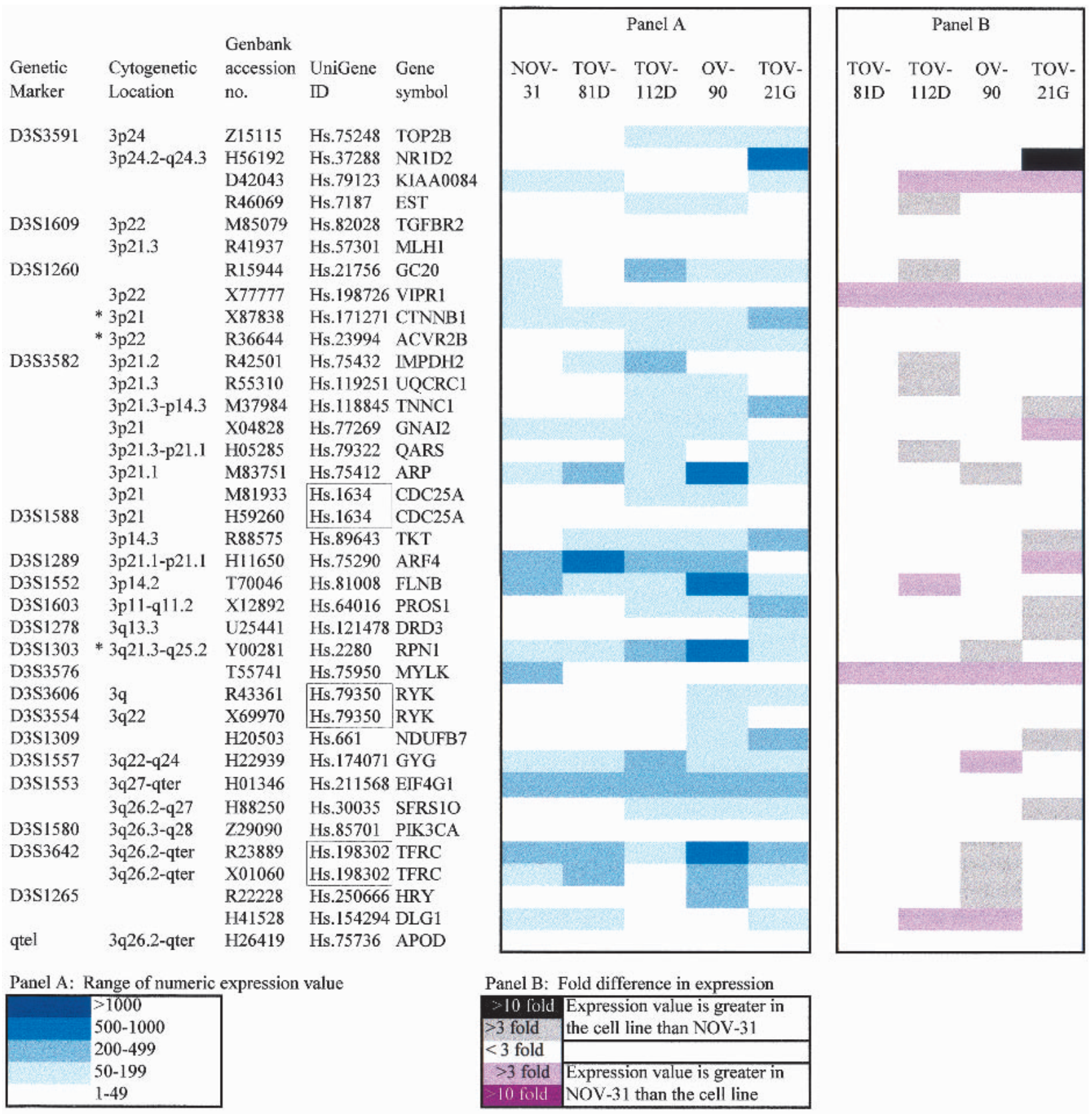

* Indicates ESTs that have no genetic map position reported in UniGene homo sapiens database.

Figure 3 A schematic representation of selected ESTs that are differentially expressed on the basis of their range of numeric expression value (Panel A) or at least a threefold difference in expression between NOV-31 and any EOC cell line (Panel B). The ESTs are displayed from the 3p telomere to the $3 q$ telomere in order of genetic and cytogenetic map position on the basis of information retrieved from the UniGene-Homo sapiens database, NCBI. A box around two ESTs indicates that they represent the same gene. The figure that displays the expression profiles for all 290 ESTs is available at http://genome.mcgill.ca/ovarian.

mouse xenografts (Provencher et al. 2000). This cell line was derived from an ovarian tumor sample from a patient with indolent disease with $>9$-yr survival (Provencher et al. 2000). The similar expression profiles of TOV-81D and NOV-31 of chromosome 3 ESTs is also consistent with the analysis of 6416 ESTs represented on the Hs6000 expression microarrays regardless of their chromosome location (Tonin et al. 2001).
In the examination of the expression profiles of the 290 ESTs, we identified 114 of these ESTs as differentially expressed on the basis of their range of numerical expression values, and 25 ESTs as differentially expressed with at least a threefold difference between NOV-31 and any EOC cell line. The majority of the ESTs $(n=92)$ that are not differentially expressed have expression values below 50 across all samples and have a low-reliability score (ambiguous) on the basis of 
Table 1. Number of ESTs That Map to Chromosome 3 and are Differentially Expressed Between NOV-31 and Each EOC Cell Line ${ }^{a}$

No. of differences No. of three-fold based on range or greater of numeric differences expression value in expression

\begin{tabular}{llr}
\hline NOV-31 vs. TOV-81D & 37 & 2 \\
NOV-31 vs. OV-90 & 62 & 10 \\
NOV-31 vs. TOV-112D & 56 & 10 \\
NOV-31 vs. TOV-21G & 64 & 12 \\
\hline
\end{tabular}

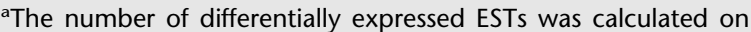
the basis of two analyses performed in Fig. 3. The first column lists the number of ESTs that were differentially expressed based on their numerically assigned expression values that were categorized on the basis of range of expression divided into the following intervals: $1-49,50-199,200-499,500-1000$ and $>1000$. The second column lists the number of ESTs that displayed at least a three-fold difference in expression between NOV-31 and any EOC cell line. The fold difference calculations were performed after the data was standardized to a minimum value of 50 .

the Affymetrix GeneChip software analysis. Noteworthy is that these ESTs were expressed with a high-reliability score in other human tissues and cell lines in independent experiments by use of the Hs6000 microarray (P.D. Lee, pers. comm.). One interpretation is that these ESTs are expressed at a low level in both NOSE and the four EOC cell lines. Seven ESTs were expressed at levels $>50$ with a high-reliability score, and are also not differentially expressed on the basis of our analyses. As all of these ESTs are not differentially expressed in EOC cell lines and NOV-31, they may not play a significant role in ovarian tumorigenesis.

Several ESTs are differentially expressed on the basis of both methods of analysis displayed in Figure 3 and, therefore, may be considered as interesting candidates for further analysis (Table 2). For example, the EST representing the argininerich protein $(A R P)$ is overexpressed in OV-90 (Fig. 3). This gene has been implicated as a possible oncogene, in that mutations were identified in the trinucleotide repeat in 11 of 37 pancreatic tumors (Shridhar et al. 1997). However, others have proposed that these sequence changes represent normal variations rather than tumor-specific changes (Evron et al. 1997; Tanaka et al. 2000). The region that was found to be variable was sequenced in OV-90 and no sequence variations were detectable (E.N. Manderson, unpubl.). Another example is the EST representing the gene for guanine nucleotidebinding protein $\alpha$-inhibiting polypeptide 2 (GNAI2 or $G_{i 2}$ ) that was found to be underexpressed threefold in TOV-21G in comparison with NOV-31 (Fig. 3). Lyons et al. (1990) reported mutations of GNAI2 in 3 of 10 endocrine tumors of the ovary. However, the relationship of these mutations to the expression levels of mRNA was not examined in their study. The mutations were found in $\operatorname{Arg} 179$, a conserved amino acid among G-proteins. This arginine is the cognate of Arg 201, which is the target for cholera toxin-catalyzed adenosine diphosphate (ADP)-ribosylation of the $\alpha$ subunit of the Gprotein $\mathrm{G}_{\mathrm{s}}$ (Cassel and Pfeuffer 1978; Abood et al. 1982). Interestingly, in TOV-21G, the EST that represents the gene for ADP-ribosylation factor $4(A R F-4)$ is also down-regulated (Fig. 3 ). ARF-4 is a guanine nucleotide-binding protein that stimulates the ADP-ribosyltransferase activity of the cholera toxin in vitro (Lebeda and Haun 1999). Two other examples are the ESTs representing vasoactive intestinal peptide receptor 1 and myosin light polypeptide kinase that are consistently underexpressed with a threefold difference in the four EOC cell lines in comparison with NOV-31, and therefore may play a role in EOC (Fig. 3).

A number of ESTs that are differentially expressed on the basis of either their range of numeric expression values or fold difference in expression between NOV-31 and any EOC cell line have been implicated previously in cancer on the basis of conventional methods of gene expression analysis. For example, the EST representing catenin $\beta 1$ (CTNNB1) was found to be overexpressed in TOV-21G, on the basis of its numeric expression values (Fig. 3, Panel A). The expression of CTNNB1 was found to be variable among 34 ovarian adenocarcinomas by immunohistochemistry, which is consistent with our results (Davies et al. 1998). Sagae et al. (1999) detected mutations in one mucinous and four endometrioid ovarian adenocarcinomas that resulted in an accumulation of the protein within the cells. These findings suggest that increased levels of catenin $\beta 1$ protein could be involved in the development of EOC by escaping regulation by the APC protein, and thus may play a role in the tumorigenesis of cell line TOV-21G. Therefore, we recommend analyzing the expression data using both methods to identify ESTs that may be important in ovarian tumorigenesis.

A review of the literature revealed that the expression of some of the genes represented on the microarray has been studied previously in EOC by use of conventional techniques such as Northern blot analysis and immunohistochemistry (Table 3). For some genes, the results obtained by the microarray are consistent with the level of expression reported in the literature. For example, topoisomerase $2 \beta$ (TOP2B) expression was found to vary in 15 tumors by Northern blot analysis (Withoff et al. 1999) and in 37 tumors by RNAse protection assay (Cornarotti et al. 1996). We also observed variable expression of TOP2B in the EOC cell lines by microarray analysis (Fig. 3). In some cases, the expression profile of some genes reported in the literature was not concordant with levels of detection by microarray analysis. For example, the EST representing transforming growth factor $\beta$ receptor type 2 (TGFBR2) revealed an absence of expression in the normal sample and the four EOC cell lines (Fig. 3). However, we have reported that this gene is expressed in the four EOC cell lines by Northern blot and RT-PCR analyses (Manderson et al. 2000). Also, others have detected its expression in ovarian tumors and cell lines by RT-PCR and in situ hybridization (Henriksen et al. 1995; Bartlett et al. 1997; Hu et al. 2000). The probe set for the Hs6000 microarray was designed on the basis of the complete cDNA of TGFBR2 (Affymetrix). The discordance in the microarray results and the Northern blot analysis serves to illustrate the limitations of microarray technology.

In conclusion, we have shown that patterns of gene expression assayed by oligonucleotide microarrays can be related to chromosomal anomalies. However, simple chromosomal anomalies, such as allelic loss, may not affect the patterns of expression in analyses based on range of numeric expression value or fold difference in expression values. This result is encouraging because it indicates that if one is using microarray technology to identify candidate genes on the basis of differential expression in a sample with $\mathrm{LOH}$, chromosome loss may not impact significantly on the comparative analyses between normal versus tumor tissue. This is exemplified by our observation that we identified a subset of ESTs 
Expression of Chromosome 3 ESTs in Ovarian Cancer

Table 2. A List of ESTs That Were Found to be Differentially Expressed Based on Their Range of Numeric Expression Value and At Least a Threefold Difference in Expression Between NOV-31 and Any EOC Cell Line

\begin{tabular}{|c|c|c|c|c|c|c|c|c|}
\hline \multirow{2}{*}{$\begin{array}{l}\text { Accession } \\
\text { no. }\end{array}$} & \multirow{2}{*}{$\begin{array}{l}\text { Gene } \\
\text { symbol }\end{array}$} & \multirow[b]{2}{*}{ Description } & \multirow[b]{2}{*}{ Function $^{\mathbf{b}}$} & \multicolumn{5}{|c|}{ Expression values and reliability scores ${ }^{a}$} \\
\hline & & & & NOV-31 & TOV-81D & TOV-112D & OV-90 & TOV-21G \\
\hline D42043 & KIAA0084 & $\begin{array}{l}\text { Hypothetical } \\
\text { protein kiaa0084 }\end{array}$ & Unknown. & $181 \mathrm{P}$ & $178 P$ & $11 \mathrm{~A}$ & $28 P$ & $55 \mathrm{P}$ \\
\hline X77777 & VIPR1 & $\begin{array}{l}\text { vasoactive } \\
\text { intestinal peptide } \\
\text { receptor } 1\end{array}$ & $\begin{array}{l}\text { This is a receptor for vasoactive } \\
\text { intestinal polypeptide. The } \\
\text { activity of this receptor is } \\
\text { mediated by G-proteins which } \\
\text { activate adenylyl cyclase. }\end{array}$ & $192 \mathrm{P}$ & $-27 \mathrm{~A}$ & $-41 \mathrm{~A}$ & $-93 \mathrm{~A}$ & $-18 \mathrm{~A}$ \\
\hline M83751 & $A R P$ & $\begin{array}{l}\text { arginine rich } \\
\text { protein }\end{array}$ & Unknown. & $112 P$ & $213 P$ & $166 P$ & $876 P$ & $108 \mathrm{~A}$ \\
\hline R15944 & GC20 & $\begin{array}{l}\text { translation factor } \\
\text { sui1 homolog }\end{array}$ & Translation factor. & $90 \mathrm{P}$ & $40 P$ & $288 P$ & $114 \mathrm{P}$ & $112 P$ \\
\hline R42501 & IMPDH2 & $\begin{array}{l}\text { Inosine } \\
\text { monophosphate } \\
\text { dehydrogenase-2 }\end{array}$ & $\begin{array}{l}\text { IMP is the rate limiting enzyme in } \\
\text { the de novo synthesis of guanine } \\
\text { nucleotides and is involved in the } \\
\text { regulation of cell growth. It may } \\
\text { also have a role in the } \\
\text { development of malignancy and } \\
\text { the growth progression of some } \\
\text { tumors. }\end{array}$ & $7 \mathrm{~A}$ & $50 P$ & $217 P$ & $14 \mathrm{~A}$ & $43 \mathrm{~A}$ \\
\hline R55310 & UQCRC1 & $\begin{array}{l}\text { ubiquinol- } \\
\text { cytochrome c } \\
\text { reductase core } \\
\text { protein I }\end{array}$ & $\begin{array}{l}\text { This is a component of the } \\
\text { ubiquinol-cytochrome c } \\
\text { reductase complex (complex iii } \\
\text { or cytochrome b-c1 complex), } \\
\text { which is part of the } \\
\text { mitochondrial respiratory chain. } \\
\text { This protein may mediate } \\
\text { formation of the complex } \\
\text { between cytochromes } \mathrm{c} \text { and } \mathrm{c} 1 \text {. }\end{array}$ & $23 \mathrm{~A}$ & $43 \mathrm{M}$ & $160 P$ & $50 \mathrm{M}$ & $-257 \mathrm{~A}$ \\
\hline R46069 & EST & & Unknown. & $44 \mathrm{P}$ & $15 \mathrm{~A}$ & $162 \mathrm{P}$ & $80 P$ & $-3 A$ \\
\hline H05285 & QARS & $\begin{array}{l}\text { glutamine-tRNA } \\
\text { synthetase }\end{array}$ & $\begin{array}{l}\text { Part of a multisubunit complex that } \\
\text { groups tRNA ligases for arg, asp, } \\
\text { glu, gln, ile, leu, lys, met and } \\
\text { pro. }\end{array}$ & $32 \mathrm{P}$ & $15 \mathrm{~A}$ & $168 P$ & $32 \mathrm{P}$ & $79 P$ \\
\hline T70046 & FLNB & $\begin{array}{l}\text { filamin B, beta } \\
\text { (actin-binding } \\
\text { protein-278) }\end{array}$ & $\begin{array}{l}\text { Dimeric actin cross-linking } \\
\text { phosphoprotein of the peripheral } \\
\text { cytoplasm, interacts with the } \\
\text { cytoplasmic tail of glycoprotein } \\
\text { GP1BA. }\end{array}$ & $320 \mathrm{P}$ & $190 P$ & $61 \mathrm{P}$ & $944 \mathrm{P}$ & $170 P$ \\
\hline R88575 & TKT & $\begin{array}{l}\text { transketolase } \\
\text { (Wernicke- } \\
\text { Korsakoff } \\
\text { syndrome) }\end{array}$ & $\begin{array}{l}\text { Key enzyme in the } \\
\text { pentose-phosphate pathway. }\end{array}$ & $36 P$ & $59 P$ & $137 P$ & $113 P$ & $417 P$ \\
\hline X12892 & PROS1 & protein S (alpha) & $\begin{array}{l}\text { Protein S, alpha coagulation factor } \\
\text { (cofactor of proC), vitamin } \\
\text { K-dependent, ligand for TYRO3, } \\
\text { AXL family of receptor tyrosine } \\
\text { kinase. }\end{array}$ & $8 \mathrm{~A}$ & $32 \mathrm{P}$ & $77 P$ & $73 P$ & $241 P$ \\
\hline H56192 & NR1D2 & $\begin{array}{l}\text { nuclear receptor } \\
\text { subfamily } 1 \text {, } \\
\text { group } D, \\
\text { member } 2\end{array}$ & $\begin{array}{l}\text { Binds to the sequences } \\
5^{\prime} \text {-aatgtaggtca- } 3^{\prime} \text { and } \\
5^{\prime} \text {-ataactaggtca- } 3^{\prime} \text {. Acts as a } \\
\text { potent competitive repressor of } \\
\text { ror } \alpha \text { function (by similarity). }\end{array}$ & $10 \mathrm{~A}$ & $10 \mathrm{~A}$ & $15 P$ & $7 \mathrm{~A}$ & $609 P$ \\
\hline M37984 & TNNC1 & troponin $\mathrm{C} 1$, slow & $\begin{array}{l}\text { Troponin is the central regulatory } \\
\text { protein of striated muscle } \\
\text { contraction. }\end{array}$ & $10 \mathrm{~A}$ & $17 \mathrm{~A}$ & $50 P$ & $98 \mathrm{P}$ & $205 P$ \\
\hline X04828 & GNAI2 & $\begin{array}{l}\text { guanine nucleotide } \\
\text { binding protein } \\
\text { (G protein), } \\
\text { alpha inhibiting } \\
\text { activity } \\
\text { polypeptide } 2\end{array}$ & $\begin{array}{l}\text { Guanine nucleotide-binding } \\
\text { proteins (G-proteins) are involved } \\
\text { as modulators or transducers in } \\
\text { various transmembrane signaling } \\
\text { systems. }\end{array}$ & $198 P$ & $122 P$ & $101 \mathrm{P}$ & $84 \mathrm{~A}$ & $16 \mathrm{~A}$ \\
\hline H11650 & ARF4 & $\begin{array}{l}\text { ADP-ribosylation } \\
\text { factor } 4\end{array}$ & $\begin{array}{l}\text { GTP-binding protein that functions } \\
\text { as an allosteric activator of the } \\
\text { cholera toxin catalytic subunit, } \\
\text { an ADP-ribosyltransferase. } \\
\text { Involved in protein trafficking. }\end{array}$ & $391 \mathrm{P}$ & $548 P$ & $225 \mathrm{P}$ & $228 \mathrm{P}$ & $19 \mathrm{~A}$ \\
\hline
\end{tabular}

(Table continued on following page.) 
Manderson et al.

Table 2. (Continued)

\begin{tabular}{|c|c|c|c|c|c|c|c|c|}
\hline \multirow{2}{*}{$\begin{array}{l}\text { Accession } \\
\text { no. }\end{array}$} & \multirow{2}{*}{$\begin{array}{l}\text { Gene } \\
\text { symbol }\end{array}$} & \multirow[b]{2}{*}{ Description } & \multirow[b]{2}{*}{ Function $^{\mathbf{b}}$} & \multicolumn{5}{|c|}{ Expression values and reliability scores ${ }^{a}$} \\
\hline & & & & NOV-31 & TOV-81D & TOV-112D & OV-90 & TOV-21G \\
\hline T55741 & $M Y L K$ & $\begin{array}{l}\text { myosin, light } \\
\text { polypeptide } \\
\text { kinase }\end{array}$ & $\begin{array}{l}\text { Phosphorylates specific serine in } \mathrm{N} \\
\text { terminus of a myosin light chain. }\end{array}$ & $290 P$ & $35 \mathrm{P}$ & $13 \mathrm{~A}$ & $-4 \mathrm{~A}$ & $-3 A$ \\
\hline Y00281 & RPN1 & ribophorin 1 & $\begin{array}{l}\text { Essential subunit of } \\
\mathrm{N} \text {-oligosaccharyl transferase. }\end{array}$ & $147 P$ & $167 P$ & $203 P$ & $556 \mathrm{P}$ & $178 P$ \\
\hline H22939 & GYG & glycogenin & $\begin{array}{l}\text { Protein primer required for the } \\
\text { biogenesis of muscle glycogen. } \\
\text { Elongation of the primer is } \\
\text { effected by glycogen synthase. }\end{array}$ & $191 \mathrm{M}$ & $113 P$ & $210 \mathrm{M}$ & $57 \mathrm{~A}$ & $120 P$ \\
\hline H41528 & DLG1 & $\begin{array}{l}\text { discs, large } \\
\text { (Drosophila) } \\
\text { homolog } 1\end{array}$ & $\begin{array}{l}\text { Interacts with the cytoplasmic tail } \\
\text { of nmda receptor subunits. } \\
\text { Associates with protein } 4.1\end{array}$ & $154 P$ & $61 \mathrm{P}$ & $49 P$ & $29 \mathrm{~A}$ & $56 P$ \\
\hline R23889 & TFRC & transferrin receptor & Cellular uptake of iron occurs via & $254 \mathrm{P}$ & $392 \mathrm{P}$ & $114 \mathrm{P}$ & $780 \mathrm{P}$ & $283 P$ \\
\hline X01060 & & & $\begin{array}{l}\text { receptor-mediated endocytosis of } \\
\text { ligand-occupied transferrin } \\
\text { receptor. }\end{array}$ & $80 P$ & $237 P$ & $45 P$ & $288 P$ & $151 P$ \\
\hline R22228 & $H R Y$ & $\begin{array}{l}\text { hairy (Drosophila)- } \\
\text { homolog }\end{array}$ & $\begin{array}{l}\text { Drosophila hairy pair rule gene } \\
\text { homolog, also homolog to rat } \\
\text { RHL, an immediated early } \\
\text { response gene to growth factor. }\end{array}$ & $-5 A$ & $1 \mathrm{~A}$ & $22 \mathrm{P}$ & $332 P$ & $27 P$ \\
\hline U25441 & DRD3 & $\begin{array}{l}\text { dopamine receptor } \\
\text { D3 }\end{array}$ & $\begin{array}{l}\text { This is one of five types ( } \mathrm{d} 1 \text { to } \mathrm{d} 5 \text { ) } \\
\text { of receptors for dopamine. The } \\
\text { activity of this receptor is } \\
\text { mediated by G-proteins which } \\
\text { inhibit adenylyl cyclase. }\end{array}$ & $-13 \mathrm{~A}$ & $10 \mathrm{~A}$ & $-31 A$ & $-4 \mathrm{~A}$ & $175 \mathrm{~A}$ \\
\hline $\mathrm{H} 20503$ & NDUFB7 & $\begin{array}{l}\text { NADH } \\
\text { dehydrogenase } \\
\text { (ubiquinone) } 1 \\
\text { beta } \\
\text { subcomplex, } 7 \\
\text { (18 kD, B18) }\end{array}$ & $\begin{array}{l}\text { Transfer of electrons from NADH to } \\
\text { the respiratory chain. The } \\
\text { immediate electron acceptor for } \\
\text { the enzyme is believed to be } \\
\text { ubiquinone. }\end{array}$ & $28 P$ & $12 \mathrm{~A}$ & $48 P$ & $62 P$ & $294 P$ \\
\hline H88250 & SFRS10 & $\begin{array}{l}\text { splicing factor, } \\
\text { arginine/ } \\
\text { serine-rich } \\
\text { (transformer } 2 \\
\text { Drosophila } \\
\text { homolog) } 10\end{array}$ & Splicing factor. & $41 P$ & $45 P$ & $148 P$ & $116 P$ & $156 P$ \\
\hline
\end{tabular}

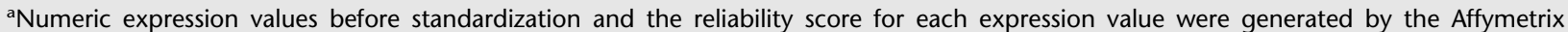
GeneChip software based on hybridization signals for probe sets representing each EST.

${ }^{b}$ The function was retrieved from the Weizman Gene Card database (www.bioinfo.weizman.ca).

that are differentially expressed between NOV-31 and any of the four EOC cell lines, and only six of these are uniquely expressed with a threefold difference in expression between NOV-31 and OV-90. In addition, we were able to identify two ESTs that are underexpressed in all four EOC cell lines in comparison with NOV-31. It will be important to validate the differential expression patterns of candidate chromosome 3 ESTs by examining their expression profiles in a larger panel of EOC tumor samples and cell lines to determine whether they play a significant role in ovarian tumorigenesis.

\section{METHODS}

\section{Source of RNA}

RNA was extracted from a primary culture of NOSE (NOV-31) and four spontaneously transformed EOC cell lines (TOV21G, TOV-81D, OV-90, and TOV-112D) with TRIsol reagent (GIBCO-BRL, Life Technologies, Inc.) as described in Tonin et al. (2001). Briefly, the EOC cell lines were maintained in OSE medium consisting of 50:50 medium 199:105 (Sigma), supplemented with $10 \%$ FBS and $2.5 \mu \mathrm{g} / \mathrm{mL}$ of fungizone and
$50 \mu \mathrm{g} / \mathrm{mL}$ of gentamicin (Kruk et al. 1990). The four EOC cell lines have been characterized extensively and described elsewhere (Provencher et al. 2000).

\section{Microarray Data Collection and Analysis}

The expression data was derived by use of the Hs6000 DNA microarray (Affymetrix) as described in Tonin et al. (2001). In summary, the hybridization target was prepared from $20 \mu \mathrm{g}$ of total RNA that was reverse transcribed to double-stranded cDNA using oligo-dT primer containing a T7 RNA polymerase-binding site. This cDNA was then in vitro transcribed to cRNA using biotinylated dUTP and dCTP. The resulting cRNA target represents a labeled 50-1000-fold linear amplification of the cDNA sample. To reduce secondary structure, the target was fragmented in $40 \mathrm{mM}$ Tris acetate, $100 \mathrm{mM}$ potassium acetate, and $30 \mathrm{mM} \mathrm{MgCl},(\mathrm{pH} 8.1)$ at $95^{\circ} \mathrm{C}$. Hybridizations were performed with $15 \mu \mathrm{g}$ of target on Affymetrix Hs6000 oligonucleotide microarrays containing probe sets for 6416 human genes (5223 known genes and 1193 ESTs). Following washing and staining, microarrays were scanned using a Hewlett Packard GeneArray scanner. Gene expression levels were calculated for each EST from the scanned image by Affymetrix 
Table 3. Correlation Between Microarray Expression Analysis and Expression Studies in EOC Using Conventional Techniques Such as Northern Blot, RT-PCR or Immunohistochemistry

\begin{tabular}{|c|c|c|c|c|c|c|c|c|}
\hline \multirow{2}{*}{$\begin{array}{l}\text { Accession } \\
\text { no. }\end{array}$} & \multirow{2}{*}{$\begin{array}{l}\text { Gene } \\
\text { symbol }\end{array}$} & \multirow[b]{2}{*}{ Name } & \multirow[b]{2}{*}{ Data reported in literature } & \multicolumn{5}{|c|}{ Expression values and reliability scores ${ }^{a}$} \\
\hline & & & & NOV-31 & TOV-81D & TOV-112D & OV-90 & TOV-21G \\
\hline Z15115 & TOP2B & $\begin{array}{l}\text { topoisomerase } \\
2 \beta\end{array}$ & $\begin{array}{l}\text { Northern blot analysis revealed } \\
\text { variable expression in } 15 \text { solid } \\
\text { ovarian tumors (Withoff et al. } \\
\text { 1999). Intertumoral variability of } \\
\text { TOP2B mRNA levels was detected } \\
\text { by RNAse protection assay and no } \\
\text { significant increase in expression } \\
\text { was detected in tumors compared } \\
\text { to normal ovaries (Cornarotti et al. } \\
\text { 1996). }\end{array}$ & $49 P$ & $47 P$ & $117 P$ & $53 P$ & $116 P$ \\
\hline M85079 & TGFBR2 & $\begin{array}{l}\text { transforming } \\
\text { growth factor } \\
\text { beta receptor } \\
\text { type } 2\end{array}$ & $\begin{array}{l}\text { Expression of TGFBR2 was detected } \\
\text { in } 14 \text { cell lines by RT-PCR (Hu et } \\
\text { al. } 2000 \text { ). Northern blot analysis } \\
\text { revealed differential expression of } \\
\text { TGFBR2 in four EOC cell lines and } \\
\text { one solid tumor (Manderson et al, } \\
2000 \text { ). Expression was detected in } \\
92 \% \text { of tumors by RT-PCR } \\
\text { (Bartlett et al. 1997). }\end{array}$ & $-53 \mathrm{~A}$ & $-70 \mathrm{~A}$ & $-67 \mathrm{~A}$ & $-170 \mathrm{~A}$ & $-62 \mathrm{~A}$ \\
\hline R41937 & MLH1 & $\begin{array}{r}\text { MutL }(E . \text { coli }) \\
\text { homolog } 1\end{array}$ & $\begin{array}{l}\text { Immunohistochemistry revealed } \\
\text { positive staining in a large fraction } \\
\text { of malignant cells in } 54 \text { solid } \\
\text { tumors (Samimi et al. 2000). } \\
\text { Colella et al (1998) were unable to } \\
\text { detect MLH1 protein by Western } \\
\text { blot in four of } 20 \text { tumors and } 5 \text { of } \\
9 \text { cell lines. }\end{array}$ & $10 \mathrm{~A}$ & $20 \mathrm{M}$ & $34 P$ & $22 \mathrm{P}$ & $20 \mathrm{P}$ \\
\hline X87838 & CTNNB1 & catenin $\beta 1$ & $\begin{array}{l}\text { Four of twenty-seven tumors showed } \\
\text { positive staining by } \\
\text { immunohistochemistry, all four } \\
\text { harbored mutations in the gene } \\
\text { (Sagae et al. 1999). Expression of } \\
\text { CTNNB1 was found to be variable } \\
\text { among } 34 \text { adenocarcinomas of the } \\
\text { ovary by immunohistochemistry } \\
\text { (Davies et al. 1998). }\end{array}$ & $192 \mathrm{P}$ & $98 \mathrm{P}$ & $153 P$ & $155 P$ & $335 P$ \\
\hline R36644 & $A C V R 2 B$ & $\begin{array}{l}\text { activin A receptor, } \\
\text { type IIB }\end{array}$ & $\begin{array}{l}\text { Expression was observed by RT-PCR } \\
\text { in } 100 \text { percent of tumor samples } \\
\text { (Zheng et al. 1998). Western blot } \\
\text { detected ACVR2B protein in } \\
\text { OVCAR-3 and SKOV3 (Ito et al. } \\
\text { 2000). }\end{array}$ & $44 \mathrm{M}$ & $29 \mathrm{~A}$ & $100 P$ & $92 \mathrm{~A}$ & $53 \mathrm{M}$ \\
\hline M81933 & $C D C 25 A$ & $\begin{array}{l}\text { cell division cycle } \\
25 \mathrm{~A}\end{array}$ & $\begin{array}{l}\text { CDC25A mRNA was detected by } \\
\text { RT-PCR in nine of } 14 \text { cell lines ( } \mathrm{Hu} \\
\text { et al. 2000). }\end{array}$ & $43 P$ & $16 \mathrm{~A}$ & $90 \mathrm{P}$ & $60 \mathrm{~A}$ & $36 \mathrm{~A}$ \\
\hline H59260 & & & & $4 \mathrm{~A}$ & $-6 A$ & $12 \mathrm{~A}$ & $5 \mathrm{~A}$ & $-4 \mathrm{~A}$ \\
\hline R43361 & $R Y K$ & $\begin{array}{l}\text { RYK receptor-like } \\
\text { tyrosine kinase }\end{array}$ & $\begin{array}{l}\text { In situ hybridization revealed minimal } \\
\text { to absent expression of RYK in the }\end{array}$ & $29 P$ & $39 P$ & $33 \mathrm{~A}$ & $92 \mathrm{P}$ & $64 P$ \\
\hline X69970 & & & $\begin{array}{l}\text { surface epithelium of normal } \\
\text { ovaries. Expression was elevated } \\
\text { primarily in the epithelium of } \\
\text { malignant tumors (Wang et al. } \\
\text { 1996). }\end{array}$ & $25 \mathrm{P}$ & $39 \mathrm{M}$ & $31 \mathrm{P}$ & $69 \mathrm{P}$ & $27 \mathrm{M}$ \\
\hline Z29090 & PIK3CA & $\begin{array}{l}\text { phosphatidylinositol } \\
\text { 3-kinase catalytic } \\
\text { subunit, alpha } \\
\text { isoform }\end{array}$ & $\begin{array}{l}\text { Increased transcription detected by } \\
\text { quantitative PCR in one ovarian } \\
\text { cancer cell line (Shayesteh et al. } \\
\text { 1999). }\end{array}$ & $10 \mathrm{~A}$ & $-3 A$ & $11 \mathrm{~A}$ & $3 \mathrm{~A}$ & $14 \mathrm{~A}$ \\
\hline R23889 & TFRC & transferrin receptor & $\begin{array}{l}\text { Immunohistochemistry revealed } \\
\text { heterogenous expression of TFRC }\end{array}$ & $254 \mathrm{P}$ & $392 \mathrm{P}$ & $114 \mathrm{P}$ & $780 P$ & $283 P$ \\
\hline X01060 & & & (Berchuck et al. 1990). & $80 \mathrm{P}$ & $237 P$ & $45 P$ & $288 P$ & $151 \mathrm{P}$ \\
\hline $\mathrm{H} 60074$ & & & & $10 \mathrm{~A}$ & $15 \mathrm{~A}$ & $24 \mathrm{~A}$ & $6 \mathrm{~A}$ & $-29 \mathrm{~A}$ \\
\hline M11507 & & & & $7 \mathrm{~A}$ & $-8 \mathrm{~A}$ & $7 \mathrm{~A}$ & $-1 \mathrm{~A}$ & $-4 \mathrm{~A}$ \\
\hline $\mathrm{H} 26419$ & $A P O D$ & apolipoprotein D & $\begin{array}{l}18 \text { of } 68 \text { ovarian tumors stained } \\
\text { positively for APOD expression } \\
\text { (Vazquez et al. 2000). }\end{array}$ & $28 \mathrm{~A}$ & $-6 A$ & $19 \mathrm{~A}$ & $29 \mathrm{~A}$ & $33 \mathrm{~A}$ \\
\hline
\end{tabular}

*Numeric expression values before standardization and the reliability score for each expression value were generated by the Affymetrix GeneChip software based on hybridization signals for probe sets representing each EST. 
GeneChip software, giving a single average difference ratio (expression value) across 20 probe pairs as well as a reliability score [Ambiguous (A), Present (P) or Marginal (M) based on the variability of hybridization with each probe set]. Expression values that were negative or zero were standardized to a minimum value of one. A query was designed to retrieve the corresponding UniGene name (cluster) for each GenBank accession number that corresponded to each EST represented on the microarray from UniGene-Homo sapiens, National Center for Biotechnology Information (NCBI) (www.ncbi.nlm.nih. gov/UniGene) in November 1999. Additional information was retrieved for each cluster, including the gene symbol, description of the gene, cytogenetic position, and location on Gene Map 98. A list of ESTs that map to chromosome 3 was generated from the mapping information collected for all ESTs on the microarray, and all information was verified and updated using the UniGene-Homo sapiens (NCBI) website in May 2000. The genetic map location of each EST was determined by the positions in $\mathrm{cM}$ of markers on chromosome 3 obtained from a comprehensive genetic map (Dib et al. 1996), which is available on the Genethon server (www.genethon. fr).

\section{ACKNOWLEDGMENTS}

We thank Todd Golub for microarray analysis, Louise Champoux for technical assistance, and Nadège Presneau for her insight and comments. This research was supported by a grant from the Medical Research Council of Canada (MRC) (to P.N.T., A.-M.M.-M., and D.P.), a grant from the MRC (to A.-M.M.-M., P.N.T., T.J.H., and D.P.), and a grant from the Canadian Genetic Diseases Network, Federal Networks of Centres of Excellence Program (to T.J.H.). E.N.M. is the recipient of a studentship from the Natural Sciences and Engineering Research Council of Canada, the Canadian Institutes of Health Research and the Fonds de Recherche en Santé du Québec (FRSQ); A.-M.M.-M. is a recipient of a Chercheur National Fellowship from the FRSQ; D.P. is a recipient of a Chercheur-Cliniciens Senior from the FRSQ; T.J.H. is a recipient of a Clinician Scientist Award from the MRC, and P.N.T. is a scholar of the MRC and the Cancer Research Society, Inc.

The publication costs of this article were defrayed in part by payment of page charges. This article must therefore be hereby marked "advertisement" in accordance with 18 USC section 1734 solely to indicate this fact.

\section{REFERENCES}

Abood, M.E., Hurley, J.B., Pappone, M.-C., Bourne, H.R., and Stryer, L. 1982. Functional homology between signal-coupling proteins. Cholera toxin inactivates the GTPase activity of transducin. $J$. Biol. Chem. 257: 10540-10543.

Arnold, N., Hagele, L., Walz, L., Schempp, W., Pfisterer, J., Bauknecht, T., and Kiechle, M. 1996. Overrepresentation of 3q and $8 \mathrm{q}$ material and loss of $18 \mathrm{q}$ material are recurrent findings in advanced human ovarian cancer. Genes Chromosomes Cancer 16: $46-54$.

Bartlett, J.M., Langdon, S.P., Scott, W.N., Love, S.B., Miller, E.P., Katsaros, D., Smyth, J.F., and Miller, W.R. 1997. Transforming growth factor- $\beta$ isoform expression in human ovarian tumours. Eur. J. Cancer 33: 2397-2403.

Berchuck, A., Olt, G.J., Soisson, A.P., Kamel, A., Soper, J.T., Boyer, C.M., Clarke-Pearson, D.L., Leslie, D.S., and Bast, Jr., R.C. 1990. Heterogeneity of antigen expression in advanced epithelial ovarian cancer. Am. J. Obstet. Gynecol. 162: 883-888.

Cassel, D. and Pfeuffer, T. 1978. Mechanism of cholera toxin action: Covalent modification of the guanyl nucleotide-binding protein of the adenylate cyclase system. Proc. Natl. Acad. Sci. 75: 2669-2673.

Cheng, P.C., Gosewehr, J.A., Kim, T.M., Velicescu, M., Wan, M., Zheng, J., Felix, J.C., Cofer, K.F., Luo, P., Biela, B.H., et al. 1996. Potential role of the inactivated $\mathrm{X}$ chromosome in ovarian epithelial tumor development. J. Natl. Cancer Inst. 88: 510-518.

Colella, G., Vikhanskaya, F., Codegoni, A.M., Bonazzi, C., D'Incalci,
M., and Broggini, M. 1998. hMLH1 and hMSH2 expression and BAX frameshift mutations in ovarian cancer cell lines and tumors. Carcinogenesis 19: 691-694.

Cornarotti, M., Capranico, G., Bohm, S., Oriana, S., Spatti, G.B., Mariani, L., Ballabio, G., and Zunino, F. 1996. Gene expression of DNA topoisomerases I, II $\alpha$ and II $\beta$ and response to cisplatin-based chemotherapy in advanced ovarian carcinoma. Int. J. Cancer 67: 479-484.

Davies, B.R., Worsley, S.D., and Ponder, B.A. 1998. Expression of E-cadherin, $\alpha$-catenin and $\beta$-catenin in normal ovarian surface epithelium and epithelial ovarian cancers. Histopathology 32: 69-80.

Dib, C., Faure, S., Fizames, C., Samson, D., Drouot, N., Vignal, A., Millasseau, P., Marc, S., Hazan, J., Seboun, E., et al. 1996. A comprehensive genetic map of the human genome based on 5,264 microsatellites. Nature 380: 152-154.

Dodson, M.K., Hartmann, L.C., Cliby, W.A., DeLacey, K.A., Keeney, G.L., Ritland, S.R., Su, J.Q., Podratz, K.C., and Jenkins, R.B. 1993. Comparison of loss of heterozygosity patterns in invasive low-grade and high-grade epithelial ovarian carcinomas. Cancer Res. 53: 4456-4460.

Ehlen, T. and Dubeau, L. 1990. Loss of heterozygosity on chromosomal segments $3 \mathrm{p}, 6 \mathrm{q}$ and $11 \mathrm{p}$ in human ovarian carcinomas. Oncogene 5: 219-223.

Evron, E., Cairns, P., Halachmi, N., Ahrendt, S.A., Reed, A.L., and Sidransky, D. 1997. Normal polymorphism in the incomplete trinucleotide repeat of the arginine-rich protein gene Cancer Res. 57: 2888-2889.

Fullwood, P., Marchini, S., Rader, J.S., Martinez, A., Macartney, D., Broggini, M., Morelli, C., Barbanti-Brodano, G., Maher, E.R., and Latif, F. 1999. Detailed genetic and physical mapping of tumor suppressor loci on chromosome $3 p$ in ovarian cancer. Cancer Res. 59: 4662-4667.

Henriksen, R., Gobl, A., Wilander, E., Oberg, K., Miyazono, K., and Funa, K. 1995. Expression and prognostic significance of TGF- $\beta$ isotypes, latent TGF- $\beta 1$ binding protein, TGF $\beta$ type I and type II receptors, and endoglin in normal ovary and ovarian neoplasms. Lab. Invest. 73: 213-220.

$\mathrm{Hu}$, W., Wu, W., Nash, M.A., Freedman, R.S., Kavanagh, J.J., and Verschraegen, C.F. 2000. Anomalies of the TGF- $\beta$ postreceptor signaling pathway in ovarian cancer cell lines. Anticancer Res. 20: 729-733.

Ito, I., Minegishi, T., Fukuda, J., Shinozaki, H., Auersperg, N., and Leung, P.C. 2000. Presence of activin signal transduction in normal ovarian cells and epithelial ovarian carcinoma. $B r . J$. Cancer 82: 1415-1420.

Kruk, P.A., Maines-bandiera, S.L., and Auersperg, N. 1990. A simplified method to culture human ovarian surface epithelium Lab. Invest. 63: 132-136.

Lebeda, R.A. and Haun, R.S. 1999. Cloning and characterization of the human ADP-ribosylation factor 4 gene. Gene 237: 209-214.

Lounis, H., Mes-Masson, A.-M., Dion, F., Bradley, W.E., Seymour, R.J., Provencher, D., and Tonin, P.N. 1998. Mapping of chromosome $3 p$ deletions in human epithelial ovarian tumors. Oncogene 17: 2359-2365

Lyons, J., Landis, C.A., Harsh, G., Vallar, L., Grunewald, K., Feichtinger, H., Duh, Q.-Y., Clark, O.H., Kawasaki, E., Bourne, H.R., et al. 1990. Two G protein oncogenes in human endocrine tumors. Science 249: 655-659.

Manderson, E.N., Mes-Masson, A.-M., Provencher, D., and Tonin, P.N. 2000. Mutations in a 10- bp polyadenine repeat of transforming growth factor $\beta$-receptor type II gene is an infrequent event in human epithelial ovarian cancer. Clin. Genet. 57: 151-153.

Mertens, F., Johansson, B., Hoglund, M., and Mitelman, F. 1997. Chromosomal imbalance maps of malignant solid tumors: A cytogenetic survey of 3185 neoplasms. Cancer Res. 57: $2765-2780$.

National Cancer Institute of Canada: Canadian Cancer Statistics 2000. Toronto, Canada, 2000.

Provencher, D.M., Lounis, H., Champoux, L., Tetrault, M., Manderson, E.N, Wang, J.C., Eydoux, P., Savoie, R., Tonin, P.N. and Mes-Masson, A.-M. 2000. Characterization of four novel epithelial ovarian cancer cell lines. In Vitro Cell. Dev. Biol. Anim. 36: 357-361.

Rimessi, P., Gualandi, F., Morelli, C., Trabanelli, C., Wu, Q., Possati, L., Montesi, M., Barrett J.C., and Barbanti-Brodano, G. 1994. Transfer of human chromosome 3 to an ovarian carcinoma cell line identifies three regions on $3 p$ involved in ovarian cancer. Oncogene 9: 3467-3474. 
Sagae, S., Kobayashi, K., Nishioka, Y., Sugimura, M., Ishioka, S., Nagata, M., Terasawa, K., Tokino, T., and Kudo, R. 1999. Mutational analysis of $\beta$-catenin gene in Japanese ovarian carcinomas: Frequent mutations in endometrioid carcinomas. Jpn. J. Cancer Res. 90: 510-515.

Samimi, G., Fink, D., Varki, N.M., Husain, A., Hoskins, W.J., Alberts, D.S., and Howell, S.B. 2000. Analysis of MLH1 and MSH2 expression in ovarian cancer before and after platinum drug-based chemotherapy. Clin. Cancer Res. 6: 1415-1421.

Shayesteh, L., Lu, Y., Kuo, W.-L., Baldocchi, R., Godfrey, T., Collins, C., Pinkel, D., Powell, B., Mills, G.B., and Gray, J.W. 1999. PIK3CA is implicated as an oncogene in ovarian cancer. Nat. Genet. 21: 99-102.

Shridhar, V., Rivard, S., Wang, X., Shridhar, R., Paisley, C., Mullins, C., Beirnat, L., Dugan, M., Sarkar, F., Miller, O.J., et al. 1997. Mutations in the arginine-rich protein gene (ARP) in pancreatic cancer. Oncogene 14: 2213-2216.

Sonoda, G., Palazzo, J., du Manoir, S., Godwin, A.K., Feder, M., Yakushiji, M., and Testa, J.R. 1997. Comparative genomic hybridization detects frequent over representation of chromosomal material from 3q26, 8q24, and 20q13 in human ovarian carcinomas. Genes Chromosomes Cancer 20: 320-328.

Sugita, M., Tanaka, N., Davidson, S., Sekiya, S., Varella-Garcia, M., West, J., Drabkin, H.A., and Gemmill, R.M. 2000. Molecular definition of a small amplification domain within 3q26 in tumors of cervix, ovary, and lung. Cancer Genet. Cytogenet. 117: 9-18.

Tanaka, H., Shimada, Y., Harada, H., Shinoda, M., Hatooka, S. Imamura, M., and Ishizaki, K. 2000. Polymorphic variation of the ARP gene on 3p21 in Japanese esophageal cancer patients. Oncol. Rep. 7: 591-593.

Tonin, P.N., Hudson, T.J., Rodier, F., Bossolasco, M., Lee, P.D.,
Novak, J., Manderson, E.N., Provencher, D., and Mes-Masson, A.-M. 2001. Microarray analysis of gene expression mirrors the biology of an ovarian cancer model. Oncogene 20: 6617-6626.

Vazquez, J., Gonzalez, L., Merino, A., and Vizoso, F. 2000. Expression and clinical significance of apolipoprotein D in epithelial ovarian carcinomas. Gynecol. Oncol. 76: 340-347.

Wang, X.C., Katso, R., Butler, R., Hanby, A.M., Poulsom, R., Jones, T., Sheer, D., and Ganesan, T.S. 1996. H-RYK, an unusual receptor kinase: Isolation and analysis of expression in ovarian cancer. Mol. Med. 2: 189-203.

Withoff, S., van der Zee, A.G.J., de Jong, S., Hollema, H., Smit, E.F., Mulder, N.H., and de Vries, E.G.E. 1999. DNA topoisomerase II $\alpha$ and $-\beta$ expression in human ovarian cancer. Br. J. Cancer 79: 748-753.

Yang-Feng, T.L., Li, S., Han, H., and Schwartz, P.E. 1992. Frequent loss of heterozygosity on chromosomes Xp and 13q in human ovarian cancer. Int. J. Cancer 52: 575-580.

Zheng, W., Luo, M.P., Welt, C., Lambert-Messerlian, G., Sung, C.J., Zhang, Z., Ying, S.Y., Schneyer, A.L., Lauchlan, S.C., and Felix, J.C. 1998. Imbalanced expression of inhibin and activin subunits in primary epithelial ovarian cancer. Gynecol. Oncol. 69: 23-31.

\section{WEB SITE REFERENCES}

www.bioinfo.weizman.ca www.ncbi.nlm.nih.gov/UniGene www.genethon.fr

Received December 10, 2000; accepted in revised form October 26, 2001.
Genome Research www.genome.org 


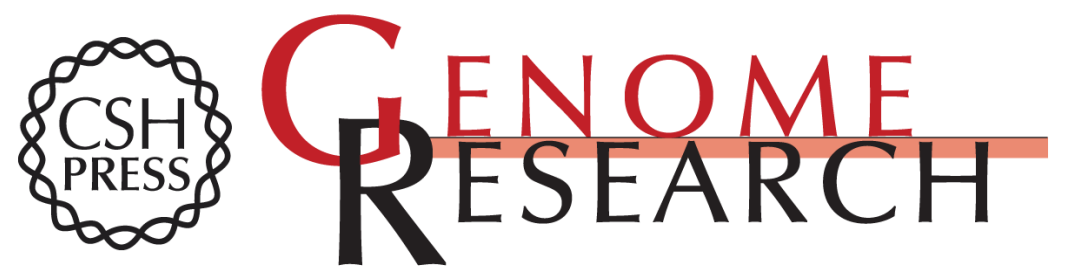

\section{Expression Profiles of 290 ESTs Mapped to Chromosome 3 in Human Epithelial Ovarian Cancer Cell Lines Using DNA Expression Oligonucleotide Microarrays}

Emily N. Manderson, Anne-Marie Mes-Masson, Jaroslav Novak, et al.

Genome Res. 2002 12: 112-121

Access the most recent version at doi:10.1101/gr.174202

References This article cites 37 articles, 8 of which can be accessed free at: http://genome.cshlp.org/content/12/1/112.full.html\#ref-list-1

License

Email Alerting

Receive free email alerts when new articles cite this article - sign up in the box at the Service top right corner of the article or click here.

\section{Affordable, Accurate Sequencing.}

